\title{
Management of Basic Unit of Organizational Structure
}

\author{
Noah Anburaj Balraj \\ Faculty of Business Administration, Asia-Pacific International University \\ noah@apiu.edu
}

\begin{abstract}
This research paper identifies components of organizational structure and the need to formulate a basic unit of organizational structure. The basic unit of any organization is vitally a propelling force that enables goal implementation and accomplishment. While organizational structures impact on the success and failure of achieving the set goal of an organization, it is extremely important to understand the elements that construct the basic structural unit of an organization. The purpose of the study is to understand and develop a substantial model of a basic structural unit of organization and how it could be managed. The methodology of the paper is through the holistic structural analysis of the basic units of living things and its relative impact on living, and relating the conceptual phenomenon of the living things to organizational structure and derive a basic unit. It is purely a qualitative study on living thing's structural and functional aspects. The data collected were observed components of structural and functional aspects of human and plant anatomy and physiology and inanimate elements. Finding depicts the basic structural unit of an organization is composed of a physical system, cognitive system, social system, and spiritual system. Contingency approach of a basic unit fits all situations with the right composition of the systems considered in this research. Creating a basic unit of an organizational structure to function continuously to eliminate overt pressure and stress on employees. Differences in the functions performed internally and externally by living things and organization are significant. Synchronizing functional units with the basic unit have an effective outcome of organizational goals. Further study could be done separately on the sustainability of organizational growth and its effective basic unit. Discussions of the research identify the management of basic unit towards organizational efficiency and effectiveness.
\end{abstract}

Keywords: Basic unit; organization; structure; management; 


\section{INTRODUCTION}

The research is collaborative with interdisciplinary in nature to identify the "basic unit" of organizational structure and how it could be managed to set its momentum in contingency. According to Miriam dictionary, basic unit refers to "one of a set of fundamental units in a system of measurement that is based on a natural phenomenon" ("Definition of BASE UNIT," n.d.). In life science, "basic unit" is more widely used term. To understand this term, we should learn from the life science for it full meaning. Why we are trying to derive meaning from life science? The simple answer is the comparison of organization and organism. These two terms share the same meaning in terms of goal accomplishments. There is more clarity in organism of how they achieve their goals. Each organism has a fixed set of goals to be achieved for living. Thus the meaning is, all life forms share the same meaning as their basic unit. Basic unit here simply the cell is the most basic structural and functional unit ("The Basic Structural and Functional Unit of Life: The Cell," n.d.). Cell is the body's basic unit ("Medical Terminology for Health Professions - Ann Ehrlich, Carol L. Schroeder Google Books," n.d.). cell is the basic unit of an organism (Tribe, Eraut, \& Snook, 1975).

Why cell is the basic unit of an organism? Cell is the basic structural unit of all living things and it possess metabolic principles (Tribe et al., 1975). It is also stated as the building blocks of all living organisms. The concept of basic unit lies in the coding of the DNA, cell metabolism to generate usable energy, metabolism for precursors, and new cell constituents (Currell \& Dam-Mieras, 2017). Considering the structural and functional aspects of a cell, expresses the highest degree of its potential of a living thing. All the living things on the earth depends upon the same environmental elements that sustain living things at the fundamental stage. The concept of basic unit of cell helps in relating its idea of conceptualizing the basic unit to an optimization. The purpose of the study is to derive a basic unit for constructing organizational structure for maximizing efficiency and effectiveness. Management of goal based formulation of basic unit is an important element for the construction of organizational structure.

\section{LITERATURE REVIEW}

The human body's function is highly complex in nature. The complexity contains the elements that define complexity. Individual, group, and organizational functionality of human 
beings are highly complex and many of those elemental functions cannot be understood. The involvement of spiritual is becoming more obviously recognized by the western and eastern scholars (Groopman, 1997). The potential of organisms are in the cells. The impact of these cells gives the state of its living. Cells could be studied for its health and diseases. These are very popularly undertaken by agricultural, industrial and tertiary sectors (Burton, 2017). It is reasonable to understand that in the cell lies the issues of the environmental impacts either positive or negative. When an embryo is developed, if we consider the embryo being internal of itself and attached to the mother for maternal components, and the mother's dependence on her externals for sustenance is of a concentric-ripple effect of diversification. This reality is inevitably significant to our understanding of the understanding of "basic unit" of an organizational structure. There is ample evidence of the development of an embryo at different stages (Winslow, 2016). Likewise, organizational development at every stage.

Human body is the highest form of basic units' configurations. It has been estimated that human body has eleven different types of specialized cell prominences. They are: stem cells, bone cells, blood cells, muscle cells, fat cells, skin cells, nerve cells, endothelial cells, sex cells, pancreatic cells, cancer cells. These cells are made into organs and organ-systems to perform functions. These specialized cells assists in performance of the organs and organsystems to achieve the goal of sustained living (writer \& BaBiology 2016, n.d.). These cells in each of the organ contributes to its cell specified functions. The specialized specific functional cells in an organ and organ-system functions to sustain living as a whole. These cells are the basic units of its organ and organ-systems. Different cells in their organ and organ-systems are subject to that cell specified function. Cells normally provides: structure and support, growth, transport, create energy, metabolic activities, and reproduction ("Six Main Cell Functions," n.d.).

Plants kingdom is also made up cells similar to animals, these cells are uniquely specialized from lower to higher levels. The specialized cells are parenchyma cells, collenchyma cells, sclerenchyma cells, xylem, and phloem. These cells perform different functions and provide structural support, and for normal cellular operations. Both animal and plant both have eukaryotic cells, which is membrane bound nucleus. There are differences between plant and animal cells in terms of size, shape, structures, and as different categories of living things (writer \& Biology 2016, n.d.).

Inanimate or non-living things are made up of atoms. Like living things, non-living things also have a basic unit and it is called as atom. The basic unit of non-living things is its atom. 
Atoms constituents' electron, proton, and neutron. The particles of an atom are constantly in a vibratory movement conducting energy ("What is the basic unit of non-living things? Quora," n.d.). Atoms provide specific matter and provide bonds and assign structures (Bader, 1985).

Organizational structure is a design resulted from the converging elements that are goal related, a set of feasible contingent elements to choose from (Tushman \& Nadler, 1978). Centralization, formalization, and integration are basic elements of an organizational structure (Dedahanov, Rhee, \& Yoon, 2017). The composition of these elements would generally determine the organizational structure. The formulation of an organizational structure is related to the internal and external structures (Kribikova, 2016). Some organizations relevance with the fundamental elements of organizational structures mentioned above are relevant in some ways and vice-versa (Green, 2002).

\section{METHODS}

The paper fundamental analysis is through the holistic structural analysis of the basic units of living things and its relative impact on living, and corelating the conceptual phenomenon of the living things to organizational structure and derive a basic unit with the context of human beings. There are two systems that blends in the functioning of an organization. They are material and social systems. So derivation of the basic unit would be an apt formulation from these systems. It is purely a qualitative study on living thing's structural and functional aspects. The data collected from human, plant, and inanimate elements were observed for it is basic units.

Authors discretion in looking at the basis unit is simply deriving the human reflection of the constituents of human living factors. We are not what we are not and we are what we are. This eloquent thought of reality is focused in stemming this research

\section{RESULTS}

Table 1. Conceptual Observation of the organizational structure

\begin{tabular}{|l|l|l|l|l|l|l|}
\hline o & Basic Units & Structural & Functional & DNA & \multicolumn{1}{c|}{$\begin{array}{c}\text { External } \\
\text { Influence }\end{array}$} & $\begin{array}{c}\text { Internal } \\
\text { Influence }\end{array}$ \\
\hline 1 & Animal Cell & $\begin{array}{l}\text { Building } \\
\text { blocks }\end{array}$ & $\begin{array}{l}\text { Specific } \\
\text { specialized cell } \\
\text { performs a }\end{array}$ & $\begin{array}{l}\text { DNA code is } \\
\text { in the nucleus }\end{array}$ & $\begin{array}{l}\text { Physical } \\
\text { environmental } \\
\text { influence }\end{array}$ & $\begin{array}{l}\text { Changes the } \\
\text { environment }\end{array}$ \\
\hline
\end{tabular}


Balraj, Management of Basic ...

\begin{tabular}{|l|l|l|l|l|l|l|}
\hline 2 & & & specific function & & $\begin{array}{l}\text { determines life } \\
\text { or death }\end{array}$ & \\
\hline 3 & & $\begin{array}{l}\text { Building } \\
\text { blocks }\end{array}$ & $\begin{array}{l}\text { Specific } \\
\text { specialized cell } \\
\text { performs a } \\
\text { specific function }\end{array}$ & $\begin{array}{l}\text { DNA code is } \\
\text { in the nucleus }\end{array}$ & $\begin{array}{l}\text { Physical } \\
\text { environmental } \\
\text { influence } \\
\text { determines } \\
\text { survival, } \\
\text { growth, and } \\
\text { bearing fruit }\end{array}$ & $\begin{array}{l}\text { Preserves the } \\
\text { environment }\end{array}$ \\
\hline $\begin{array}{l}\text { Atom } \\
\text { Ananimate }-\end{array}$ & $\begin{array}{l}\text { Building } \\
\text { blocks }\end{array}$ & $\begin{array}{l}\text { Specialization is } \\
\text { in the } \\
\text { configuration of } \\
\text { an atom }\end{array}$ & $\begin{array}{l}\text { DNA is in the } \\
\text { configuration } \\
\text { of electron, } \\
\text { proton and } \\
\text { neutron. }\end{array}$ & $\begin{array}{l}\text { Influenced by } \\
\text { the external } \\
\text { energy levels. } \\
\text { Animal and } \\
\text { plant kingdoms } \\
\text { depends on } \\
\text { inanimate }\end{array}$ & $\begin{array}{l}\text { Changes } \\
\text { itself as } \\
\text { influenced by } \\
\text { the external }\end{array}$ & \\
\hline
\end{tabular}

The above analysis considers physical factors. The basic unit is expressed as physicalstructural-functional unit that builds the living or nonliving things. These physical-structuralfunctional units designed are to initiate a platform to produce benefit as an outcome in response to the environmental stakeholders. In nature, except humans, all others function in a fixed range as determined in its basic units. Humans to function in a similar positivity, every human should be integrated (acquired) with the physical basic unit and the components of cognitive, social, with the spiritual implication of living. Only if the spiritual element is established, there will be positive benefits with zero negative impact. "Jesus said unto him, Thou shalt love the Lord thy God with all thy heart, and with all thy soul, and with all thy mind... Thou shalt love thy neighbor as thyself" ("Bible Gateway passage," n.d.). This truth is valid in identifying the basic unit that will function with absolute benefit to the stakeholders of an organization.

\section{Basic Unit of an Organization Structure}

A basic unit of an organizational structure is the ability to establish the stated goal(s). Composition of specialization through automation (involuntary) element and non-automation (voluntary) of free will action that affect the goal establishment (Haggard, Clark, \& Kalogeras, 2002). Functional compositions and structural compositions are concocted to establish a deliberate physical, cognitive, social and spiritual systems to be integrated to equip the goal producing stencil. This is to be based on the values of the organization and society (Wart, Denhardt, \& Denhardt, 2019). Basic unit of an organization structure includes- 
1. physical system - physicalism in completeness supports cognitive, social, and spiritual (Angel, 2010). Physical systems designs that supports production process is critically important to achieve specifications of product quality and design (Ravichandran \& Rai, 2000). Engineering view of physical or manufacturing process is a priority or process-based over operational improvement for better organizational structure (Dillon, 2019).

2. Cognitive-technical know-how. Accurate fact and meaning to producer and customers is a need (Bly, 2013). Technical know-how is a core and complementary to business (Pataco \& Silva, 2019). Cognitive-technical knowhow is another layer that overlaps with other elements (Boerner, Rubin, \& Severgnini, 2019). Without this element there is no function whatsoever to any organization. As important stakeholder in the general environment, it expresses the efficiency.

3. Determined social need (value). Evolving norms and beliefs of either positive or negative impacts with either growth or antigrowth. Values and beliefs boost economic growth and reduce human suffering (“A society's values and beliefs matter for its economy," 2019). Organizational values are simply a reflection of the stakeholders' values from the society. As an organization is located and enveloped by a society the values and beliefs are as embraced. With environmental influence the organizations decisions also reflect the values (Peterson \& Barreto, 2018). National cultural from east to west influence the organizations in their basic unit composition element (Swoboda \& Batton, 2019). The social need is reflected from the social values of any given geo-location.

4. Spirituality of loving God and your target market (neighbor). Most organizations are accustomed to physical layouts and cognitive-technical know-how and they customarily replace the work of loving their target market with the cognitivetechnical know-how. Because, the gravity of physical system is in the visibility and there is a tendency to remember only those we see and ignore the target market we don't see. To accelerate the view to our target market, we should be placing their pictures in the boardroom and cubical to make their presence felt to be considered their genuine need requirements. Organizations cannot create a product without living in the present. To live in the present, organizations needs God in the first place. The workplace spirituality is seemingly gaining importance 
from early 1920s, an organization is a community and its spirituality matters (Rao, n.d.). Associating meaning and purpose of doing the goal in the organization (Farmer, Allen, Duncan, \& Alagaraja, 2019). Spirituality connects us to God and our creator. It is like our mobile device being connected to the tower or satellite for connecting with others. Human mind to be connected with loving-kindness to one another always comes from the connection with the God of heaven and earth and human.

\section{Implications}

1. Individuals, groups and organizations are benefited by aligning consumers' or our target market's needs with right basic unit of organizational structure in producing products and services.

2. Human beings are made with propensity to live with the four domains viz., physical, cognitive, social, and spiritual. All four domains together form the basic unit for performance (living) to live and grow and benefit others. Organization's benefits are directly proportionate to target markets benefits.

3. The composition of physical system, cognitive system, social need and spirituality of the organization are simply the reflection of humans who are in an internal environment and task and general of the external environment.

4. Of all the four, the greatest is the dependence on God for establishing a better basic unit as it is denoted as basic unit in a changing world (contingency).

5. Basic unit is the building block of an organization and if it is rightly composed, it achieves the goal with the highest positivity.

\section{DISCUSSION}

Basic unit of an organizational structure is a new conceptual view that has effective drive for managerial supremacy. The challenging side is about the initiation and sustenance with contingency management of the organization. Basic unit is coupled with transformational leadership with beliefvalue reformation. Deriving the concept from science, we understand the DNA of an organization from the perspective of its domains where actual living takes place. As mentioned above, these domains are-physical system, cognitive system, social need and spiritual transformation. These domains are incorporated in humans at the DNA level. A holistic reality of an organization needs to consider the formulation of "basic unit" for functioning-performing or living in day-to-day conditions. One might give importance to most of the domains of human living, if the basic unit of an organization is represented less than hundred percent of the domains, then the representation is 
inappropriate. Representation of such idea would create imbalance or cloning the natural way. The purpose of "basic unit" formulation in an organization is to create natural well-being of humanity. As how an organism functions with a basic unit, so should an organization. The producing benefits through the right basic unit of organizational structure is to rectify the incomplete or improper alignment of target market's needs with organizational goal production to satisficing consumers of their needs.

\section{Conclusion}

Four major domains should be layered together to perform predominantly out of factors of human living. To live with the knowledge of God is understanding and this should be the main stream agenda. What is an organization's building block? The answer is derived from science and it is the "basic unit." In the model below, it gives a glimpse of the "basic Unit" of human living. The center is the represented the DNA as spiritual (it's about loving God and loving your neighbor, then social, cognitive, and physical which envelops the whole.

The study is limited to only deriving the "basic unit" the detailed explanation will be in the next research paper.

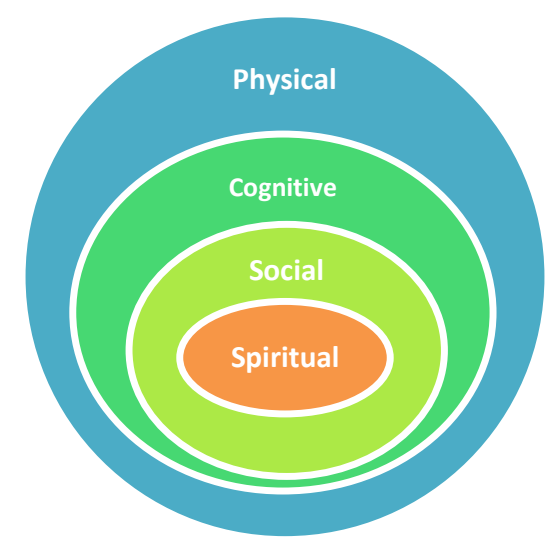

Figure 1. the "basic Unit" of human living

\section{REFERENCES}

A society's values and beliefs matter for its economy: Free exchange. (2019, July 23). The Economist (Online); London. Retrieved from https://search.proquest.com/docview /2262850456/abstract/F07113B236724C53PQ/1

Angel, L. (2010). The importance of physicalism in the philosophy of religion. International Journal for Philosophy of Religion; Dordrecht, 67(3), 141-156. http://dx. doi.org/10.1007/s11153-009-9223-z 
Bader, R. F. W. (1985). Atoms in molecules. Accounts of Chemical Research, 18(1), 9-15. https://doi.org/10.1021/ar00109a003

Bible Gateway passage: Matthew 22 - King James Version. (n.d.). Retrieved September 29, 2019, from Bible Gateway website: https://www.biblegateway.com/passage/ ?search=Matthew $+22 \&$ version=KJV

Bly, B. (2013). Technical Know-How. Target Marketing; Philadelphia, 36(6), 8-9. Retrieved from https://search.proquest.com/docview/1399962863/abstract/4EE30CC6971142 2EPQ/1

Boerner, L., Rubin, J., \& Severgnini, B. (2019). A Time to Print; a Time to Reform. IDEAS Working Paper Series from RePEc; St. Louis. Retrieved from https://search.proquest.com/docview/2236982148/F6B5D8EA8194B22PQ/11

Burton, T. M. (2017, January 19). Mystery Fungus Sparks Crisis at NIH --- Medical trials, treatments at National Institutes of Health have stalled. Wall Street Journal, Eastern Edition; New York, N.Y., p. A.1. Retrieved from https://search.proquest.com /docview/1859709149/abstract/EAD4ACF01C0245ACPQ/1

Currell, B. C., \& Dam-Mieras, R. C. E. (2017). Biosynthesis \& Integration of Cell Metabolism. Butterworth-Heinemann.

Dedahanov, A. T., Rhee, C., \& Yoon, J. (2017). Organizational structure and innovation performance. Career Development International; Bradford, 22(4), 334-350. http://dx.doi.org/10.1108/CDI-12-2016-0234

Definition of BASE UNIT. (n.d.). Retrieved September 29, 2019, from https://www.merriamwebster.com/dictionary/base+unit

Dillon, A. P. (2019). A Study of the Toyota Production System: From an Industrial Engineering Viewpoint. https://doi.org/10.4324/9781315136509

Farmer, M., Allen, S., Duncan, K., \& Alagaraja, M. (2019). Workplace spirituality in the public sector: A study of US water and wastewater agencies. International Journal of Organizational Analysis; Bingley, 27(3), 441-457. http://dx.doi.org/10.1108/IJOA11-2017-1281

Green, K. W. (2002). Just -in -time selling: Relation to market orientation, organizational structure and organizational performance (D.B.A., Louisiana Tech University). Retrieved from https://search.proquest.com/docview/275918787/abstract/9B79E841A3D4EBAPQ/4

Groopman, J. E. (1997, May 7). The anatomy of awareness. Wall Street Journal, Eastern Edition; New York, N.Y., p. A, 16:4. Retrieved from https:// 
search.proquest.com/docview/398606028/abstract/3771179E8ED54216PQ/1

Haggard, P., Clark, S., \& Kalogeras, J. (2002). Voluntary action and conscious awareness. Nature Neuroscience, 5(4), 382-385. https://doi.org/10.1038/nn827

Kribikova, P. (2016). Organizational Structure and Performance. Aktual'ni Problemy Ekonomiky = Actual Problems in Economics; Kiev, (175), 109-118. Retrieved from https://search.proquest.com/docview/1762414059/abstract/57B4663C24D44EAPQ/12

Medical Terminology for Health Professions - Ann Ehrlich, Carol L. Schroeder - Google Books. (n.d.). Retrieved September 29, 2019, from https://books.google .co.th/books?id=HX7FFOfN14EC\&pg=PA33\&dq=basic+unit+of+human+body\&hl= en\&sa $=X \& v e d=0 a h U K E w j k x 5$ LYlfXkAhUxIbcAHVBMAO4Q6AEIODAC\#v=onep age \&q=basic\%20unit\%20of\%20human\%20body\&f=false

Pataco, T., \& Silva, M. (2019). Do You Speak Wine Tourism? International Conference on Tourism Research, 389-395,X. Retrieved from https://search.proquest.com /docview/2288610288/abstract/F6B5D8EA8194B22PQ/7

Peterson, M. F., \& Barreto, T. S. (2018). Interpreting societal culture value dimensions. Journal of International Business Studies; Basingstoke, 49(9), 1190-1207. http://dx.doi.org/10.1057/s41267-018-0185-1

Rao, S. R. (n.d.). What is Workplace Spirituality? Retrieved September 29, 2019, from https://www.citeman.com/8980-what-is-workplace-spirituality.html

Ravichandran, T., \& Rai, A. (2000). Quality management in systems development: An organizational system perspective. MIS Quarterly; Minneapolis, 24(3), 381-415. Retrieved from https://search.proquest.com/docview/218119429/ abstract/D803C74273E04489PQ/3

Six Main Cell Functions. (n.d.). Retrieved September 29, 2019, from Sciencing website: https://sciencing.com/six-main-cell-functions-6891800.html

Swoboda, B., \& Batton, N. (2019). National cultural value models and reputation of MNCs. Cross Cultural \& Strategic Management; Bingley, 26(2), 166-198. http://dx.doi.org/10.1108/CCSM-05-2018-0061

The Basic Structural and Functional Unit of Life: The Cell. (n.d.). Retrieved September 29, 2019, from https://2012books.lardbucket.org/books/an-introduction-to-nutrition/s0701-the-basic-structural-and-funct.html

Tribe, M. A., Eraut, M. R., \& Snook, R. K. (1975). Basic Biology Course Unit 1: Volume 2, Electron Microscopy and Cell Structure. CUP Archive.

Tushman, M. L., \& Nadler, D. A. (1978). Information Processing as an Integrating Concept in Organizational Design1. Academy of Management Review. https://doi.org/10.5465/amr.1978.4305791 
Wart, M. V., Denhardt, K. G., \& Denhardt, K. G. (2019, February 21). Organizational Structure: A Reflection of Society's Values and a Context for Individual Ethics. https://doi.org/10.4324/9781482290042-14

What is the basic unit of non-living things? - Quora. (n.d.). Retrieved September 29, 2019, from https://www.quora.com/What-is-the-basic-unit-of-non-living-things

Winslow, R. (2016, May 5). U.S. News: New Look at Early Embryo Growth. Wall Street Journal, Eastern Edition; New York, N.Y., p. A.8. Retrieved from https://search.proquest.com/docview/1786757643/abstract/EAD4ACF01C0245ACPQ 12

writer, R. B. R. B. is a science, \& BaBiology 2016, educator who has covered biology for T. since $1997 \mathrm{H}$. writing is featured in K. A. (n.d.). 10 Different Cell Types in the Body Work Together to Create Humans. Retrieved September 29, 2019, from ThoughtCo website: https://www.thoughtco.com/types-of-cells-in-the-body-373388

writer, R. B. R. B. is a science, \& Biology 2016, educator who has covered biology for T. since $1997 \mathrm{H}$. writing is featured in K. A. (n.d.). Learn About Plant Cell Types and How They're Like Animal Cells. Retrieved September 29, 2019, from ThoughtCo website: https://www.thoughtco.com/what-is-a-plant-cell-373384 